\title{
EU Conflict Resolution Policy Towards the South Caucasus
}

\author{
By Esmira Jafarova*
}

\section{Introduction}

Relations between the European Union and the states in the South Caucasus region have long been on the back burner of the academic research world, with little attention devoted to the analysis of EU policy in this part of Europe. Things improved slightly with the nascence of various EU mechanisms and instruments in the region, such as the Special Representative's institute, the inclusion of the region into the ENP, and the Eastern Partnership, which brought EU relations with the region to the forefront.

However, the EU's contribution to conflict resolution efforts in South Caucasus still remains under-researched. This essay therefore, aims to share insights on the EU's conflict resolution approach towards the long-standing conflicts in the South Caucasus region, namely the Nagorno-Karabakh conflict between Armenia and Azerbaijan and the Abkhazian and South Ossetian conflicts within Georgia.

For this purpose, at the outset, I will first provide an empirical perspective on EU relations with the South Caucasus republics, with a focus on EU conflict resolution strategy. This will be followed by an analysis based upon the theoretical assumptions of intergovernmentalism and neofunctionalism, as appropriate. The evaluation of EU conflict resolution strategy using the assumptions of neofunctionalism and intergovernmentalism as analytical tools is deemed to be the best method for tackling such a broad issue and examining in detail the EU's logic for preferring a particular type of conflict resolution approach.

\section{The European Union: Low Profile vs. the Necessity for a Stronger Role}

The European Union's role in conflict resolution in the South Caucasus region could be assessed in two different periods. The first period can be described as marking a shift "from low profile to increasing attention," and would run until the year 2003, when the EU Special Representative for South Caucasus was appointed. The second period is characterized by "increased role/facilitation-mediation activity," which would cover the period since 2003 until the present. This is a conditional classification, which I have designed to better explain the EU role. Since the EU's role in

Esmira Jafarova holds a Ph.D. from the University of Vienna, an M.A. from the Central European University in Budapest, and a B.A. from Baku State University in Azerbaijan. She is also a graduate of the Geneva Center for Security Policy and the Diplomatic Academy of Vienna. 
conflict resolution in the South Caucasus region started to gain some momentum after 2003, having a quick sketch of the EU's profile in the security issues of South Caucasus before that date would be useful.

\section{First Period: From "Low Profile" to Increasing Attention}

For quite some time the EU has maintained a rather distant approach towards facilitating the conflict resolution process in the South Caucasus. The principled position taken by the EU towards conflict resolution in the region was mainly one of passive political involvement, which was confined to political declarations and communications. Nevertheless, since the independence of these republics in 1991, and the entry into force of Partnership and Cooperation Agreements in 1999, the EU actively used its different assistance programs aimed at promoting democracy, civil society, economy, etc. EU relations with these states were also framed by unilateral EU aid to these countries, in the form of financial assistance, humanitarian aid, food security, rehabilitation, and technical assistance. ${ }^{1}$ The EU programs of Technical Assistance for Commonwealth of Independent States (TACIS), Transport Corridor Europe Caucasus Asia (TRACECA), and Interstate Oil and Gas Transport to Europe (INOGATE) were also tools of EU policy in the region. ${ }^{2}$

In Abkhazia and South Ossetia, the EU was particularly active in rendering economic rehabilitation and assistance. It aimed to become the largest donor in Abkhazia by dedicating a considerable amount of money (an estimated EUR 25 million) to humanitarian, rehabilitation, and reconstruction projects in the wake of the GeorgianAbkhaz conflict. The EU-funded projects were depoliticized, and were not dependent on progress in the conflict resolution field. ${ }^{3}$ In South Ossetia, however, the EU's participation was slightly more visible than in Abkhazia. The EU projects in South Ossetia were not limited only to infrastructure, agriculture, economic rehabilitation, and related projects that had no direct relevance to the conflict resolution process. In South Ossetia, the EU Council adopted three Joint Actions under the CFSP allocating

Total EU assistance to Armenia from 1991-2000 was EUR 286.13 million (no figures available for 2001-2004); to Azerbaijan from 1992-2003, EU aid totaled EUR 399.674 million; to Georgia from 1992-2003, EUR 369.43 million euro. See http://www.europa. eu.int/comm/external_relations.

2 The EU developed the Program of Technical Assistance for Commonwealth of independent states (TACIS) in 1991.

3 "Conflict Resolution in the South Caucasus: The EU's Role," International Crisis Group Europe Report, No. 173 (20 March 2003): 16-18. 
EUR 500,000, which were intended for the OSCE Mission in Georgia, to help the latter to finance the Joint Control Commission (JCC). ${ }^{4}$

In order to supervise how the given money was used, the EU Commission started to attend the JCC negotiations in 2001. This did not imply the EU's full-fledged participation within the JCC format, although this was Georgia's long-standing objective. However, the EU managed to employ its financial power to gain at least some political clout in the negotiation process around the South Ossetian conflict, even though it was rather trivial. Apart from assistance to the JCC activity, the EU has funded projects in South Ossetia amounting to roughly EUR 8 million between 1997 and 2006, which were directed to rehabilitation activities in various fields. ${ }^{5}$ Nonetheless, as was mentioned above, aside from making such financial contributions, the EU did not play a significant political role in the conflict resolution process.

In Abkhazia, the EU was not involved in any similar ways in the negotiation process, although three member states - Germany, France and the United Kingdomwere members of the UN Secretary-General's Group of Friends. ${ }^{6}$ EU assistance in Abkhazia was not directed to changing the conflict settlement process or to contributing to the promotion of cooperation and interaction between the parties. The biggest achievement of the EU in Abkhazia was considered to be its assistance in civil society projects. In general, the EU seemed to attach more importance to having a higher profile in South Ossetia compared to Abkhazia, due to the fact that the South Ossetian conflict was thought to be easier to solve than the Abkhazian conflict. Moreover, early resolution of the South Ossetian conflict appeared to be more desirable due to the region's geographic proximity to the Georgian capital Tbilisi. ${ }^{7}$ With respect to Nagorno-Karabakh, the same pattern of EU involvement through economic and confidence building programs was not the case, mostly due to the fact that Baku officially rejected any such activity before the final solution of the conflict. ${ }^{8}$

4 Ibid. With the "Agreement on Principles of the Settlement of the Georgian-Ossetian conflict between Georgia and Russia,» signed in Sochi in 1992, a Joint Control Commission (JCC) was established with the participation of Georgian, Russian, North and South Ossetian representatives, plus the OSCE. The JCC was tasked with numerous undertakings, including coordinating the activities of a Joint Peace Keeping Force (JPKF) in the zone of conflict. ("Georgia's South Ossetia conflict: make haste slowly," International Crisis Group Europe Report No. 183 (7 June 2007), 1.

5 "Conflict Resolution in the South Caucasus," 16-18.

6 Nicu Popescu, "Europe's Unrecognized Neighbors: The EU in Abkhazia and South Ossetia," Center for European Policy Studies Working Document, No. 260 (March 2007),

13. The Group of Friends of the Secretary-General was a formation created within the UN in 1997 to discuss the Abkhazian conflict, and included representatives from Germany, France, Russia, the United Kingdom, and the United States.

7 Ibid., 16-20.

8 "Conflict Resolution in the South Caucasus," 16-18. 
This indirect participation in conflict resolution in the South Caucasus republics probably served the EU's conviction that fostering economic development and civil society through such a policy would decrease the danger of conflicts re-emerging, thus creating the prerequisites for lasting stability. However, compared to other problem regions, which were more immediately in the EU's neighborhood, like the Eastern European countries and the Balkans, the region of South Caucasus has never been high on the EU's external political agenda. There was not a clear EU strategy or policy toward the states of the region, given the fact that the EU's agenda has been overburdened with other tasks, such as enlargement, the EU Constitution, etc. Still, while securing some role for itself in the region through assistance projects, the EU preferred primarily to continue its political aloofness and confined its political role only to supporting the activities of the UN and the OSCE.

Nevertheless, the political changes that were afoot in view of the penultimate wave of eastern enlargement were also followed by revisions to the EU's external policy towards the South Caucasus. Moreover, with Turkey's possible membership on the horizon, the enlarged EU would have been an immediate neighbor of the region. Therefore, easing the potential threats posed by the unresolved conflicts in the South Caucasus became one of the conspicuous issues on the EU's external policy agenda. Increasing EU attention to the region was also conditioned by the involvement of EU economic interests in a region that was steadily becoming a strategic hub due to its vast hydrocarbon resources and its position as a corridor for critical energy and transportation infrastructure connecting Central Asia and the Caucasus, especially the Caspian Basin, with Europe. The EU's concern for its own energy security and its goal to diversify its sources of crude energy necessitated obtaining a higher profile in the South Caucasus region.

Against this backdrop, the EU intermittently sent some signals that it was willing to play a larger role in the region. For instance, there were several debates in the EU starting in 1999 over making the EU role in the region more effective. ${ }^{9}$ The attempts to define the position of the South Caucasus region on the EU's political agenda continued in 2001 as well. At first, the European Parliament called for an EU strategy

9 For instance, a communication on EU relations with the South Caucasus states under the PCA of June 1999 emphasized the persisting conflicts in the region as the root causes of the region's political, economic, and humanitarian problems. In the Commission's view, EU assistance could be effective only if the conflicts were settled and regional cooperation became possible. See Dov Lynch, "The EU: Towards a Strategy," The South Caucasus: A Challenge for the EU, Chaillot Papers 65 (Paris: European Union Institute for Security Studies, December 2003), 181. Chris Patten and the late Anna Lindh published a joint article in the Financial Times on February 20 saying that "the EU cannot afford to neglect the Southern Caucasus" and advocating a more targeted EU political role to support conflict resolution. Cited in Lynch, 184. 
towards the region under the name of the "Southern Dimension." Then, the Swedish presidency of the EU declared the South Caucasus to be one of the EU's main foreign policy priorities in the first half of 2001, and in the same year, the first visit of the EU Troika to the region took place. ${ }^{10}$

In its Security Strategy of 2003, the EU stressed that it should "take a stronger and more active interest in the problems of the Southern Caucasus, which will in due course also be a neighboring region." the region led to the appointment of an EU Special Representative (SR) to the South Caucasus region in 2003. This decision had henceforth paved the way for more active EU mediation/facilitation activity towards conflict resolution in the South Caucasus region.

\section{Second Period: An Increased Role Desired, but Volatile}

As was illustrated in the preceding section, it was not until 2003 that the EU undertook more direct facilitation activity in conflict resolution in the South Caucasus. The mandate of the Special Representative generally included the tasks to "contribute to the prevention of conflicts," to "assist in conflict resolution," "intensify EU dialogue with the main interested actors concerning the region," "assist the Council in further developing a comprehensive policy towards the South Caucasus," and other similar tasks of assistance. ${ }^{12}$ The institute of the Special Representative was tasked to travel to the region several times a year and conduct meetings with officials of the conflicting parties, as well as with members of the civil society.

The next milestone in EU-South Caucasus relations was the inclusion of the three republics into the European Neighborhood Policy in 2004. This was a long-awaited decision, since at the inception of the ENP these counties were excluded from it and were only mentioned in a footnote to the policy as possible neighbors. However, one can also rightly assume that the decision to include Armenia, Azerbaijan, and Georgia into the ENP sooner than expected was to a considerable extent influenced by the Rose Revolution in Georgia in November 2003, which was viewed by the EU as a harbinger of a strengthening democratic state-building process in the region. It is also noteworthy that the region was expected be an even nearer neighbor to the EU's borders after the membership of Romania and Bulgaria and possible future enlargement to the Balkans, and maybe Turkey as well. Therefore, it was assumed that the

10 Lynch, "The EU: Towards a Strategy," 183-84.

11 Article 3 of Council Joint Action, 2003/496/CFSP, concerning the appointment of an EU Special Representative for the South Caucasus.

12 Article 3 of Council Joint Action, 2003. With the next Council Joint Action (2006/121/ CFSP, of 20 February 2006), the Swedish diplomat Peter Semneby took over from Heikki Talvitye. Official Journal of the EU, L 49/14, 21/2/2006. 
EU could not afford to overlook the South Caucasus region any longer and leave it outside of the benefits offered by various EU policy frameworks.

After the inclusion of the South Caucasus states in the ENP in 2004, ENP Action Plans (APs) with these three countries were adopted on 14 November 2006 with the aim of helping them to move closer to European standards. ${ }^{13}$ Nonetheless, despite the obvious attempts by the EU to increase its profile in conflict resolution in the South Caucasus, the ENP did not manage to deliver it. Both the ENP Strategy Paper and the individual APs touched upon the issue of conflict resolution, but in all documents these references were quite ambiguous. For instance, the ENP Strategy Paper is very vague in this regard: "Increased efforts to promote the settlement of the conflicts in the region and to develop good neighborly relations are needed. Concrete steps forward need to be made by each of the three countries. ... The ENP should reinforce EU's contribution to promote these objectives." 14

The policy could have been more effective and successful had it developed a mechanism or a policy to increase the EU's role in conflict resolution beyond just facilitation and leaving the solution of the problems to the states themselves. Nonetheless, without adding much flesh to the bones in this respect, the ENP simply carried on the traditionally established distant attitude maintained by the EU towards the problems of the region.

A similar pattern was followed in the ENP Action Plans, which also fell short of making conflict resolution a priority in the EU's relations with the involved countries. Conflict resolution was left on the margins of the APs with each of the republics, and was lumped into a larger list of priorities under the category "political dialogue and reform." Regardless of the increasing understanding that it was necessary for the EU to raise its profile in conflict resolution in the region, the thrust of the APs was again on factors that are believed to help with democratization and state building, such as economics and political change..$^{15}$

The ENP also attributes significance to people-to-people contacts, socialization, confidence-building measures, and regional cooperation, which testifies to the thought that by focusing on dialogue and cooperation the EU hoped to create a security environment in which the pending conflicts could be resolved. Therefore, the ENP is viewed to be an "indirect conflict prevention policy," and another expression of the fact that the EU continued to evade a more direct role in conflict resolution. ${ }^{16}$

13 See the European Neighborhood Policy, available at http://ec.europa.eu/external_relations/enp/index_en.htm.

14 "European Neighbourhood Policy: Strategy Paper," Communication from the Commission, COM (2004) 373 final (Brussels, 12 May 2004), 11.

15 "Conflict resolution in the South Caucasus," 9.

16 Andrei Belyi, "EU External Energy Policies: A Paradox of Integration," in Europe's Global Role: External Policies of the European Union, ed. Jan Orbie (Farnham, UK: Ashgate, 2009), 222. 
The ambiguity in the EU's policy towards the issue of conflict resolution manifested itself very vividly in the designation of the ENP APs. For example, in the AP with Azerbaijan, the EU emphasized the importance of respect for sovereignty and territorial integrity, while in the AP with Armenia it underlined the right of self-determination, which testifies to the absence of any well-thought-out EU policy towards conflict resolution in the South Caucasus.

The same was also the case in Georgia. In almost every one of its statements the EU expressed its unequivocal support for Georgia's territorial integrity. However, it was wary of undertaking a direct mediation role in conflict resolution before the August 2008 conflict with Russia, and seemed to be content with leaving this task on other organizations' plates while quietly observing Russia's growing leverage over the state of affairs. Thus, even if the ENP APs were supposed to establish conflict resolution as one of the priorities for action, the EU at that time was still avoiding any direct involvement in conflict resolution. It preferred the APs to focus on "soft security" issues as a means for conflict resolution, with a particular focus on political and economic reform issues, which would supposedly help strengthen the republics' democratic state building and their ability to resolve the pending conflicts. ${ }^{17}$

As was noted above, another milestone of the ENP was to foster regional cooperation in areas like economics, business, social policy, trade, environment, justice and home affairs (particularly on border management, migration and asylum, the fight against organized crime, trafficking of human beings, illegal immigration, terrorism, money laundering, etc.), joint infrastructure and security projects in the sectors of energy and transport, civil society development, and other issue areas that are quite substantial and require strong commitment on the part of the relevant states. ${ }^{18}$ While doing so, however, no proper differentiation was made between the relevant regions. For instance, if regional cooperation could be a useful exercise in the countries of Eastern Europe, in the South Caucasus or in the Middle East the effect would be rather the opposite, since these two regions differ from the former in terms of their security contexts.

Although in the ENP APs each of the three republics indicated its individual priorities for action, and their interaction within the ENP format is generally built on these priority areas, the EU did not miss its chance to stress the necessity of regional cooperation, especially in the above mentioned areas, being convinced that this is indispensable in order to achieve better results. The idea of regional cooperation was also mentioned in the AP for each of the three republics. For example, in Azerbaijan's AP strengthening of regional cooperation was placed under priority number ten, while holding spots number eight and five in Armenia's and Georgia's APs respectively.

\footnotetext{
Ibid., 9-11.

18 "European Neighbourhood Policy: Strategy Paper," Communication from the Commission, COM (2004) 373 final (Brussels, 12 May 2004), 21.
} 
In this context, and given the obstacles to all-inclusive regional cooperation, it is a bit naive to assume that the ENP objective "to foster closer cooperation among the EU's neighbors themselves" could meet with success in the South Caucasus prior to finding a cure for the region's problems. The idea of regional cooperation cannot be promoted equally in the region of the Southern Mediterranean, Eastern Europe, and the South Caucasus without taking into account the situation on the ground.

Even beyond the letter of the ENP itself, the EU has attempted to underline a special niche role for the ENP in promoting regional cooperation in the South Caucasus. For example, in its resolution of 20 May 2010 "on the need for an EU Strategy for South Caucasus," the European Parliament made an implicit reference to the EU's intention to further focus on the issue of regional cooperation within the ENP. The following excerpt from the resolution serves as a good substantiation of this view: "The European Parliament ... recognizes regional cooperation as a necessary condition for confidence-building and the reinforcement of security, in accordance with the ENP priorities...." ${ }^{19}$ Within this premise, much will depend on the ability of the EU to strike the right balance by cooperating with the states in the region on a bilateral basis, through the agreed individual APs, without pushing for full regional cooperation.

In order to hold the thought of policy frameworks similar to the ENP, let me jump to the year of 2009 and note that alongside the ENP, the Eastern Partnership Initiative (EPI), a new framework that was initiated in May 2009, also seems to be far from designing any clear-cut strategy with regard to conflict resolution. ${ }^{20}$ Although it is a new initiative, the EPI is often seen as the continuation of the ENP in many dimensions, and implies the conclusion of comprehensive free trade agreements with those countries that are eager and capable for deeper economic integration with the EU. ${ }^{21}$

The policy also envisages extended cooperation in the field of democracy and good governance, energy security, security sector reform, environmental issues, etc. The intended bilateral Association Agreements that are to be the actual realizations

19 European Parliament Resolution "On the need for an EU strategy for the South Caucasus" (20 May 2010) (2009/2216(INI)).

20 The Eastern Partnership Initiative was launched in May 2009 under the Czech EU Presidency, and aims at deepening bilateral cooperation in number of areas (economy, energy, border management, democratic state building, rule of law, etc.) with six countries in the ENP: Azerbaijan, Armenia, Georgia, Ukraine, Moldova, and Belarus. The ENP and the Eastern Partnership Initiative have differences and similarities. There is a view that, going forward, the ENP will lose its importance for the countries that are involved in the Eastern Partnership Initiative, since the latter provides deeper integration opportunities. However, sometimes, it is also referred to as a continuation of the ENP in an Eastern dimension.

21 "Eastern Partnership," European Union External Action, available at (http://eeas.europa. eu/eastern/index_en.htm. 
of the proposed policy within the EPI are being negotiated with each of the six countries. However, in the same vein as the ENP, the EPI also maintained the EU's passivity in conflict resolution and further validated the EU's inclination to solve the persistent conflict issues though economic assistance and stabilization instead of by direct involvement in the mediation of the conflicts. Some view the EPI as another "attempt to camouflage the weakness of the Neighborhood Policy."22

In order to increase its visibility, the EU referred to the scope of the European Security and Defense Policy (ESDP) missions and launched the first mission of this kind - a rule of law mission - on the territory of the former Soviet Union, in Georgia in 2004, the primary focus of which was on policing and civilian administration issues. Furthermore, in 2005 the EU established a small Border Support team in order to assist in the monitoring of the Georgian-Russian border, since the OSCE Border Monitoring Mission ended in 2005 because of the Russian veto. This operation was initiated as a part of the EU Special Representative's efforts in the South Caucasus. $^{23}$

These missions were also examples of the mainstream EU policy of preference for "soft security" measures directed at the achievement of long-term results, rather than direct involvement in conflict resolution processes. The EU has felt more comfortable with a post-conflict rehabilitation and peace-building role, and has remained cautious to undertake a deeper involvement in conflict resolution. ${ }^{24}$

Although the calls for increased attention, the appointment of the Special Representative, and inclusion in the ENP pointed to the fact that there was a degree of intent within the EU to play a more active role in the region, this role was still less influential when compared, for instance, to other actors in the region like the U.S., Russia, Iran, and Turkey. In this context, this policy of keeping a "low profile" seems to constitute an apparent contradiction with the EU's security and energy interests in

22 Nona Mikhelidze, "Eastern Partnership and Conflicts in the South Caucasus: Old Wine in New Skins?", 10; available at http://www.iai.it/pdf/DocIAI/iai0923.pdf.

23 Magdalena Frichova Grono, "Georgia's Conflicts: What Role for the EU as Mediator?" IFP Mediation Cluster, Initiative for Peacebuilding (March 2010): 11; available at http:// www.initiativeforpeacebuilding.eu/pdf/Georgia_March2010.pdf.

24 "Conflict resolution in the South Caucasus: the EU's role," 2. 
the region..$^{25}$ However, this is a topic for separate research, and will not be analyzed in this article.

On the whole, while embarking upon some activities in the conflict resolution field, the EU seemed to try to strike a balance between the necessity to gain more visibility and not threatening Russian interests in the region. Irrespective of the fact that the EU had an interest in maintaining security and stability in the region, it was not a principal actor in taking up the task of promoting regional security; this role was left to the OSCE in Nagorno-Karabakh and South Ossetia, and to the UN in Abkhazia.

At this juncture it should also be noted that out of the three republics, Georgia was the most outspoken and adamant demanding more direct EU involvement in conflict resolution. It had long asked for the EU to participate in the framework of the JCC talks, requested an EU contribution towards border security in Georgia, ${ }^{26}$ and did not miss its chance to employ its pro-European vocation and an image of "developing democracy" within the South Caucasus to drag the EU into a greater political role

25 The forecasts point toward increasing EU energy import dependence, which will grow even faster with recent and forthcoming enlargements of the organization. For instance, some figures suggested by the International Energy Agency (IEA) indicate that oil demand in the EU will increase by an average of 0.5 percent annually until 2030 , while gas demand will grow at 2.1 percent annually over the same period. See John Gault, "EU Energy Interests and the Periphery," in European Union Foreign and Security Policy: Towards a Neighbourhood Strategy, ed. Roland Dannereuther (Routledge: London and New York, 2004), 171. Forecasts also predict that EU oil production will decline from roughly 7 million barrels a day currently to less than 3 million barrels a day by 2030. (Ibid.) The Caspian region one of the main sources (among others, mainly Russia and Middle East) where the EU's energy supply comes from and which may be an alternative source for reducing the EU's energy dependency on the Middle East. The importance of the energy resources of the Caspian Basin is also recognized by the EU itself. The Commission Communication "On the development of energy policy for the enlarged European Union, its neighbours and partner countries" states that "the European Union has a specific interest in the extensive oil and gas reserves of the Caspian Basin which will in the future contribute to security of supply in Europe." "On the development of energy policy for the enlarged European Union, its neighbours and partner countries," Communication from the Commission to the Council and the European Parliament, COM (2003) 262 final, (Brussels, 13 May 2003), 12.

26 Upon the termination of the OSCE Border Monitoring operation in 2005 in Georgia, the EU extended the Special Representative's mandate to also cover border-related issues with the aim to facilitate confidence building between Georgia and Russia and help Georgia to carry out the reform of its border guards. Georgia wanted an EU border assistance mission, which would monitor the Georgian-Russian border. In 2006 Georgia requested the EU to deploy a mission that would monitor the demilitarization in the zone of conflict. However, the EU was rather reluctant to fulfill this request out of the consideration that activities having a military or police component could have been perceived as a threat on Russia's part. See "Conflict Resolution in the South Caucasus," 24. 
in the resolution of its conflicts. Georgia wanted the EU to commit itself to a direct mediation of the conflicts in Abkhazia and South Ossetia, perhaps also at the expense of a possible confrontation with Russia.

However, the EU did not share Georgia's desire to entangle itself deeper in conflict resolution activity, and was rather unenthusiastic about being saddled with this role, particularly since it could bring the EU to loggerheads with Russia. Despite the fact that the EU had passed several resolutions on the situation in Georgia addressing various events happening in the zones of conflict, a more direct form of EU involvement did not happen. ${ }^{27}$ It was only after the conflict of August 2008 that the EU assumed a more prominent role in conflict resolution in Georgia, even though it was necessitated by the desperation that swallowed the country in the aftermath of the Georgian-Russian war.

After the tragic events of August 2008, the EU had no choice other than to become directly involved in conflict resolution in Georgia. The French Presidency of the Council of the EU, led by President Nicolas Sarkozy, negotiated a six-point ceasefire agreement on 12 August, and after these developments the EU established an additional EU Special Representative position for Georgia and deployed an EU Monitoring Mission in the Georgian-controlled territories. Now, at the multi-party Geneva negotiations the EU acts as one of the negotiation parties. ${ }^{28}$

27 Some of them are the European Parliament Resolutions of 26 October 2006, 29 November 2007, and 5 June 2008.

28 After the events of August 2008, a new negotiation format - the Geneva talks, which were launched in November 2008 and hosted by the European Union - became the main forum for the discussion and interaction among the parties to the South Ossetian and Abkhazian conflicts, once the UN and OSCE-led processes came to an end. This format, along with the EU, also included representatives from the UN and OSCE as well as Georgia, Abkhazia, South Ossetia, and Russia. About sixteen rounds of talks have been held so far, and those talks addressed a wide range of issues such as stability and security in the region, return of IDPs and refugees, non-use of force, international security guarantees etc. One of the stumbling blocks of the talks became the status issue, since Tbilisi completely refuses to recognize the independence of the two regions and therefore declines signing any international agreements with them, including the agreement on non-use of force. The necessity of signing such an agreement had been advocated by Russia and South Ossetia, inasmuch as they consider the Medvedev-Sarkozy agreement not to be sufficient to ensure the independent republics' security from a future possible offensive launched by Tbilisi. Tbilisi on its part maintains that this kind of non-use of force agreement could be concluded only with Russia. See "Geneva Talks on Caucasus End in Deadlock," AbkhazWorld (9 June 2010); available at http://www.abkhazworld.com/headlines/489-geneva-talks-june-2010. $\mathrm{html}$. 
The ceasefire agreement included points such as rejection of the use of force, a lasting cessation of hostilities, unimpeded access for humanitarian aid workers, a demand for the Georgian forces to withdraw to their usual barracks, and for the Russian forces to step back to their positions prior to the start of hostilities, and the initiation of international discussions on security and stability arrangements for Abkhazia and South Ossetia. Although the achievement of such a plan represented good progress per se, it did not contain any deadlines for the intended actions. Therefore, on $8 \mathrm{Sep}-$ tember, the sides concluded a second ceasefire plan that indicated concrete measures for the implementation of both agreements. ${ }^{29}$

The EU Special Representative for Georgia, Pierre Morel, was appointed on 25 September 2008; his mandate envisaged the preparation of international negotiations considered in the 12 August 2008 ceasefire agreement, representing the EU in this format, and assisting in the implementation of the 12 August and 8 September 2008 ceasefire agreements. The EU Monitoring Mission (EUMM) was established upon the EU's decision to set up a civil monitoring mission in Georgia; more than 200 monitors were deployed in Georgia on 1 October 2008. The Mission's main task was to monitor the implementation of the August and September 2008 agreements and the withdrawal of Russian and Georgian armed forces to their positions held before the war. However, the EUMM could get access only to Georgian-controlled territories, despite the fact that its mandate extended to the entire Georgian territory. ${ }^{30}$

The value of the EUMM has increased significantly after the cessation of the OSCE and the UN presences, especially the OSCE military monitoring observers in Georgia ${ }^{31}$ since the EUMM came to be the only international presence on the ground that could do at least some monitoring of the situation, in spite of the fact that they were not permitted by Russia to access the breakaway regions.

\footnotetext{
Frichova Grono, "Georgia's Conflicts.”

Ibid.

31 Russia became intransigent to agree to the extension of the OSCE mandate, and hence the OSCE Mission in Georgia had to put up with its closure at the beginning of 2009. Consequently, all the activities implemented by the OSCE Mission in Tbilisi, including its military monitoring activities in the region, had to be terminated. Moreover, in June of 2009, the UNOMIG (UN Military Observer Mission) had to cease its activity by virtue of the Russian veto on the resolution submitted by Austria, Croatia, France, Germany, Turkey, the United Kingdom, and the United States to the UN Security Council, which aimed to extend the mandate of the mission. Russia was unhappy with the fact that the said resolution reemphasized Georgia's territorial integrity, and therefore refused to endorse the document, which it described as disregarding the new changes and being "based on old realities." The Mission's closure had actually created a security void. See "UN Mission in Abkhazia and Georgia to Close," Current Digest of the Post-Soviet Press 24/061, (15 June 2009); available at http://diib.eastview.com.browse/doc/20591296.
} 
Hence, the EU began to pursue a direct role in conflict resolution and mediation. Doubtless, the execution of increased EU mediation activity in Georgia's conflicts was not flawless, and suffered a number of limitations and setbacks that adversely affected the EU's role. These limitations will be discussed in a later section of the essay dealing with an analysis of the EU's effectiveness.

As for elaborating a cohesive EU policy towards the entire region underlining the nuts and bolts of the EU strategy, this has increasingly become one of the primary topical issues in the EU's approach to this part of the world. In recent years there were several resolutions passed by the EU calling for a more effective EU policy toward the South Caucasus. For example, in its resolution of 17 January 2008 on "a more effective EU policy for the South Caucasus: from promises to actions," the EU once again validated its adherence to peaceful resolution of the conflicts in the South Caucasus region within the existing formats, through advocating different programs directed at the promotion of confidence building and conflict transformation. It expressed its support for the sovereignty and territorial integrity of Georgia, as well as Azerbaijan, but once again sent mixed signals by also emphasizing the importance of the right to self-determination when it came to the Nagorno-Karabakh conflict. ${ }^{32}$

In the next resolution of 20 May 2010 "on the need for an EU Strategy for South Caucasus", the European Parliament made another pledge to support the conflict resolution process through confidence building, reconstruction, and rehabilitation activities. The resolution also holds the promise that the entry into force of the Lisbon Treaty would precipitate more EU activism in the region. It praises the work of the EU's Monitoring Mission in Georgia and envisages a greater possible EU role in the Nagorno-Karabakh conflict through instituting an EU mandate for the French CoChair of the Minsk Group. ${ }^{33}$

The most outstanding element of this resolution seems to be the EU's call on its High Representative for Foreign Affairs and Security Policy to be "more actively involved in conflict resolution processes." However, despite the fact that this resolution is a leap forward in prescribing a more direct role for the EU in conflict resolution in the South Caucasus, it is still quite vague, since it again puts much emphasis on rehabilitation and assistance programs, and the EU's contribution to peace-building and conflict management, supporting civil-society projects, etc. ${ }^{34}$ Last but not least, it should be once again stated that despite all the efforts to increase the EU's involvement in conflict resolution in the South Caucasus, its role still remains inferior to other regional players, like the United States, Russia, and Turkey.

32 European Parliament Resolution, "On a more effective EU policy for the South Caucasus: from promises to actions," (17 January 2008) (2007/2076 (INI)).

33 "Draft Report on an EU Strategy for the South Caucasus," European Parliament Committee on Foreign Affairs (11 January 2010) (2009/2216 (INI)).

34 Ibid. 


\section{Evaluation of the EU Conflict Resolution Approach}

After providing some background for the EU's approach towards the South Caucasus region and its conflict resolution policy, with its fluctuating dynamics and changing trends, this section of this essay will be devoted to the conceptual/theoretical evaluation of the EU's role in the process of conflict resolution in the South Caucasus. The EU's involvement in the South Caucasus region and its role in facilitating conflict resolution will be explained through intergovernmentalist and neofunctionalist approaches to the study of European integration, as follows:

- The EU's distant approach towards conflict resolution and its indirect role in facilitating conflict resolution is due to the lack of interest on the part of EU member states to dedicate attention to the region (intergovernmentalist assumption)

- The subsequent increase of the EU's profile in the region after the events of August 2008 in Georgia was due to the initiative and leading role of an EU member state (intergovernmentalist assumption)

- The EU's emphasis on the necessity of regional cooperation on practical issues (economy, border issues) serves the EU's conviction that cooperation on more practical issues will lead to the expansion of cooperation on issues of high politics, which subsequently will lead to the attainment of peace in the relevant conflict cases (neofunctionalist assumption).

The fact that the EU kept a low profile in the conflict resolution process in the South Caucasus for a considerable period of time was mostly due to the unwillingness of the EU member states to undertake more commitments in a larger geographical area that transcends its own back yard. For a long time, the South Caucasus was a "white spot" on the EU foreign policy agenda, with no EU interest whatsoever in having a say in regional issues. As was already noted, there was no clear EU strategy or policy towards the states of the region, because of other priorities on EU's external agenda like the security situation in the Balkans and Eastern Europe, EU enlargement, the European Constitution, etc., which kept the South Caucasus on the fringes of the already existing list of priorities.

Even after the increasing economic and strategic significance of the region was recognized, which mostly gained momentum after the 1994 oil agreements, where many European oil companies became shareholders in national oil concerns, the EU maintained its silence until the end of the 1990s and the beginning of the 2000s, when it finally started to display an interest in taking a more active stance in the region. Still, this role was not prominent, and in spite of the EU's declared desire to com- 
mit to more active involvement in regional issues, its role was limited to assistance, facilitation, and promotion of different kinds of aid, programs, etc., allowing other regional players and organizations to do the heavy lifting.

This brief historical summary of the genesis of EU policy towards the South Caucasus was intended to explain the first intergovernmentalist assumption. We know that from the perspective of European integration, intergovernmentalism explains the dynamics and the nature of the integration process through prisms of decisions and policies adopted by the respective EU member states. The emphasis of intergovernmentalist approaches is mainly on states and their national interests, which they consistently defend, especially in highly political issue areas such as foreign policy, security, and defense. ${ }^{35}$

Intergovernmentalism suggests that the EU's distant stance toward conflict resolution was due to a lack of interest on the part of EU member states to dedicate attention to the region. Indeed, intergovernmentalism has always been strong in the external domain of the EU, which is very much dependent on the interests and preferences of its individual member states.

In addition, the difficulty of attaining political solidarity and convergence of interests on the issues related to foreign policy has always been the EU's most glaring weakness. However, in this particular case, it would perhaps be erroneous to assume that there was a level of debate and divergence of opinion over the necessity of making a stronger EU commitment to the region among the EU member states as a result of which the EU continued to maintain its presence beneath the surface. Conversely, the problem mainly lay in the fact that there was no or only meager interest on the part of the EU member states to engage with the region on a more dynamic level, which was subsequently reflected in the formation of overall EU policy vis-à-vis the region and the EU's distant stance toward South Caucasus issues, including conflict resolution. Thus, referring to the first intergovernmentalist assumption, and using an intergovernmentalist focus on national governments and their preferences as a starting point, it becomes possible to explain the nature of the EU's conflict resolution policy in the South Caucasus.

Developing further on intergovernmentalist suppositions, it could be maintained that even when the EU decided to take a more active role in the region in view of the region's rising economic and strategic significance, its conflict resolution strategy more or less remained the same: maintaining a distant and indirect approach. It could be assumed that the underlying reason for such a disparity between the increasing EU role in the region on one hand and a limited commitment to conflict resolution issues on the other was largely conditioned by a reluctance on the part of the EU states to

35 Neill Nugent, The Government and Politics of the European Union (Durham, NC: Duke University Press, 2006), 565. 
encroach upon what Russia considered to be its sphere of influence and any probable conflicts that could have emerged with Russia on this score. This supposition seems particularly valid given the fact that some of the core EU member states, such as France and Germany, did not want to jeopardize their close economic cooperation with Russia over the tiny region.

Moreover, some EU member states (France, Germany, the United Kingdom) were acting in their national capacities as members of the Group of Friends of the Secretary-General of the UN on Georgia and as the co-Chair of the OSCE Minsk Group (France) to mediate the Nagorno-Karabakh conflict. Given their separate roles within other organizations, there was no desire on the part of these and other member states to also engage the EU in active conflict resolution in the South Caucasus; rather, they were satisfied with supporting the work of other existing formats in the field. Against this backdrop, it is a germane occasion to hypothesize that the interests of the EU member states account for EU policy fluctuations towards the region.

A more direct EU role in the conflict resolution process in the South Caucasus following the events of August 2008 could be seen as raising the EU's profile in conflict resolution. However, I would argue that this change was in fact necessitated by the extreme conditions in Georgia in the aftermath of the Russian offensive, when none of the other regional or international organizations, such as the UN or the OSCE (not to mention the Russian-led CIS) could mediate peace and establish a representation in the conflict area due to strong Russian influence on their decision making. ${ }^{36}$

Nonetheless, many analysts afterwards suggested that the EU's decision to mediate the 12 August 2008 ceasefire agreement was mostly due to the personal initiative of French President Sarkozy and the fact that France held the Presidency of the Council of the European Union at the time, rather than a well-considered and desired policy option of the entire EU as such. It was later observed that Sarkozy did not miss the occasion to underline that that the achievement of the ceasefire was due to France's efforts and not those of the EU. For instance, in his statement at a preelection meeting in Nimes he noted, "if Georgia was not wiped from the map ... that is because France, while it held the presidency of the European Union, shouldered its responsibilities so that Europe could take action...." ${ }^{37}$

Further, in an article in the Washington Post, Sarkozy described in detail how he achieved the ceasefire between Georgia and Russia and convinced the Russians to agree to withdraw their forces from Georgia. He maintained, "At the behest of the French presidency, Europe put itself on the front lines from the outset of hostilities to

36 Russia is a permanent member of the UN Security Council and holds a veto on unfavorable decisions, while the OSCE could be manipulated due to its consensus principle.

37 "Sarkozy: Europe's Peacemaker or Was it all a Spin?", in "Charlemagne's Notebook", Economist.com (8 June 2009), quoting Sarkozy statement at a pre-election meeting in Nimes on 5 May 2009. 
resolve this conflict. ... It was the European Union through France that created a space for diplomacy by quickly proposing reasonable terms for a ceasefire and rendering the political cost of pursuing war exorbitant for both parties...." ${ }^{n 8}$

The reflection on the paragraphs above on the more direct role for the EU, which became possible with President Sarkozy's mediation efforts, leads to the reasoning that even when there was a dire necessity for action in the region, it became possible only due to the individual initiative of an EU member state, in this case France, whose president, beyond attempting to ease the conflict, also aimed to strengthen his country's image (and also his own). It is believed that Sarkozy grabbed the momentum to put France back on a track of prestige after his predecessor Jacques Chirac surrendered France's erstwhile eminence in the EU and on the international stage. ${ }^{39}$ Thus, the second intergovernmentalist assumption, which suggested that the subsequent increase of the EU's profile in the region after the events of August 2008 was due to the initiative and leading role of an EU member state, seems to be valid and relevant.

The general landscape of the overall EU approach towards conflict resolution was drawn around the EU's belief that conflict resolution in the South Caucasus region will be best attained through long-term objectives and commitments to promote democracy, development and, most importantly, regional cooperation and dialogue.

EU persistence on approaching the South Caucasus through various institutional arrangements such as ENP and EPI, by means of which it has tried to promote various types of reform and regional cooperation in many areas, could be perhaps be evaluated through a neofunctionalist logic, which argues that membership in common arrangements changes the way national interests are understood in the relevant interest groups and governments. According to this view, once they have been initiated, institutions turn into supranational entities that become the driving force of further integration and can have an effect on the perception of national interests. ${ }^{40}$

Moreover, it was described earlier that regardless of the specific security situation on the ground and the unwillingness of some states to engage in all-inclusive regional cooperation, the EU insists on the promotion of regional cooperation in the South Caucasus through the ENP in areas like economy, business, social policy, trade, environment, border management, joint infrastructure and security projects in the sectors of energy, transport, and other areas.

38 Nicolas Sarkozy, "Europe Gets Started on Quelling a Crisis," Washington Post (18 August 2008); available at http://www.washingtonpost.com.

39 Ari Indyk, "Nicolas Sarkozy's Mediation of the Crisis in the Caucasus," PiCA, A Global Research Organization (2009); available at http://www.thepicaproject.org/?page_id=124.

40 Arne Niemann, Explaining Decisions in the European Union (Cambridge: Cambridge University Press, 2006), 15. 
This EU approach is seemingly based on the notion and logic of spillover ${ }^{41}$ of neofunctionalism, according to which further cooperation might follow on in other relevant fields (functional spillover), which might also lead to the increased integration and socialization of elites with gradual approximation of interests (political spillover). This in its turn will make it easier for the respective governments to negotiate and come to a common position, which might eventually result in the achievement of a peaceful solution to their lingering conflicts.

Besides, it could also be suggested that the EU's focus on promoting various forms of policies and instruments (ENP, EPI) towards various regions, including South Caucasus, corresponds with the cultivated spillover model, according to which supranational institutions, once they are established, will become the driving forces of integration, since they are interested in the further development of the process. To conclude this analysis, it should nonetheless be once again reiterated that the application of integration theories to EU policy towards conflict resolution in the South Caucasus is different from the EU case, since in application to the South Caucasus the word integration is to be interpreted as cooperation.

41 One of the important tenets of the neofunctionalist approach is the concept of spillover, which refers to the dynamics and development of further integration processes, maintaining that regional integration in one area would lead to the integration in other fields. Most importantly, it is assumed that once the process is set in motion, spillover becomes automatic and is not reliant on other extraneous factors. Niemann, Explaining Decisions in the European Union, 15. It is noted that a certain action with respect to a particular goal leads to a situation where the initial objective could be attained only by undertaking subsequent actions, which further creates situations where more integration is needed. See Ben Rosamond, "The Uniting of Europe and the Foundation of EU Studies: Revisiting the Neofunctionalism of Ernst B. Haas," in The Disparity of European Integration: Revisiting Neofunctionalism in Honor of Ernst B. Haas, ed. Tanya Börzel (New York: Routledge, 2006), 28. Decisions to embark on economic integration lead to economic and political spillovers, which might be "unintended or unwanted consequences of earlier decisions" and become the driving force for subsequent integration processes. Several types of spillovers are distinguished; however, the most prevalent ones, which are also relevant to our research, are functional, political and cultivated spillovers. According to the functional spillover effect, cooperation in some areas of the economy generates certain necessities to expand cooperation in other relevant fields, thus further inciting future cooperation. Political spillover mostly becomes the consequence of economic integration. It happens when cooperation in some areas enables the relevant supranational officials to undertake the role of "political entrepreneurs" in other realms. Political spillover also denotes that as a consequence of the enhanced degree of elite integration and socialization, slow but steady approximation of interests and expectations occurs. Cultivated spillover suggests that, once established, supranational institutions turn into the propellants of integration, since they are interested in the further development of the process. See Dimitrius N. Chryssochoou, Theorizing European Integration (Routledge: New York, 2009), 29; and Niemann, Explaining Decisions in the European Union, 43. 
The reason why the EU hoped to bring peace to the region via an assistance policy in various areas, and other indirect tools targeted at democracy, state-building, and civil society development was because of its conviction that such changes will make the parent states more attractive to their secessionist parts, which might then pursue reintegration. However, this "conviction" was the declared or the visible side of the distant EU attitude towards the conflict resolution process, while the underlying implication could be related to higher geopolitical considerations, such as EU member states' reluctance to clash or interfere with Russia's deeply entrenched leadership role on regional issues. ${ }^{42}$

\section{General Conclusions}

After briefly analyzing the EU's role in conflict resolution in the South Caucasus, first, its distant attitude and afterwards increased role in the Georgian conflict; secondly, the importance it attaches to the role of institutions and various instruments in promoting stability, cooperation, and conflict resolution, the following general conclusions can be drawn regarding the EU's role in conflict resolution in the South Caucasus:

- Due to the reluctance of the EU member states to commit themselves to the promotion of regional security in the South Caucasus and the priority attached to its direct neighborhood in the Balkans and Eastern Europe, the region and its problems have long been disregarded in the EU's foreign policy agenda (first intergovernmentalist assumption). The increasing EU role in the Georgian conflicts was due to the initiative of an individual EU member state (second intergovernmentalist assumption).

- Despite the fact that following the August 2008 war the EU had to play a stronger role in conflict resolution in the South Caucasus, its role is still inferior to those of other regional actors, such as Russia, Turkey and the U.S.

- The EU's approach to the South Caucasus through various institutional arrangements such as ENP and EPI is dictated by its belief that by fostering various reforms, regional cooperation in many areas, and the effect of spillover that such cooperation patterns might create, it will be easier for the respective governments to negotiate and come to a speedy peaceful resolution of their various conflicts (neofunctionalist assumption).

42 Mikhelidze, "Eastern Partnership and Conflicts in the South Caucasus," 3. 
Even the above described European Parliament resolution, which underlines the necessity for a stronger EU role in conflict resolution and is a leap forward in ascribing a more direct role for the EU in conflict resolution in the South Caucasus, is still quite vague, since it again puts significant emphasis on rehabilitation and assistance programs, and the EU contribution to peace-building and conflict management, supporting civil-society projects, etc. ${ }^{43}$

In the Nagorno-Karabakh conflict, the EU's role unfortunately did not alter visibly even after the appointment of the EU Special Representative and the increased EU role in Georgia after August 2008. As was mentioned above, the EU Special Representative mainly performs a facilitation/assistance role, without bringing weightier input that would generate direct EU involvement in conflict resolution beyond offering support for the OSCE-led process. The EU's role is predominantly narrowed down to some political declarations and expressing support for the efforts of the Minsk Group.

Increased EU visibility in mediating the South Caucasus conflicts has thus been left within the boundaries of the Georgian conflicts, and did not apply to the Nagorno-Karabakh conflict, towards which the EU supposedly tries to maintain a balanced approach by avoiding any partiality in favor of either of the parties, Armenia or Azerbaijan. The EU unremittingly evades expressing any support for the territorial integrity of Azerbaijan, without making equal references to the right of self-determination. This has turned into a stumbling block in EU-Azerbaijani relations, since Baku does not hide its disappointment with the EU's reticence on this issue. This is evidently different from the Georgian case, where the EU never hid its perspicuous support for the territorial integrity and sovereignty of Georgia.

Mainstream EU policy revolves around the promotion of various institutions, such as ENP and EPI through which the EU hopes to attain regional cooperation on many fronts and thus assist the states themselves to find a solution to their conflicts. However, the issue of regional cooperation and a continuous focus on its promotion may also be a challenge to the effectiveness and success of the ENP, and the overall EU policy in the South Caucasus, if the EU continues to employ the ENP as another instrument to promote all-inclusive regional cooperation in the South Caucasus region under the present circumstances, which is dominated by the absence of fundamental preconditions such as security and stability, mutual trust, and confidence. This aspect may be one of the main hurdles for the policy's opportunities to be exploited to the maximum in the states of the South Caucasus region. Despite all these limitations and shortcomings, however, the institute of the EU Special Representative has done positive work in shuttling between the conflicting parties and facilitating dialogue.

43 "Draft Report on an EU Strategy for the South Caucasus," European Parliament Committee on Foreign Affairs (11 January 2010) (2009/2216 (INI)). 
Having a lesser role compared to other more prominent actors, and limiting its increased mediation activity only to the Georgian conflicts, the EU keeps on offering its traditional model for the peaceful solution of conflicts, through confidence building, cooperation, cohabitation, and respect for diversity. That said, the conventional European approach to conflict resolution through cooperation and confidence building aimed at final peace through gradual rapprochement seems unfortunately not to be a viable option in the South Caucasus today. This is mostly due to the fact that the conflicts in the South Caucasus are far more deeply rooted than is understood in Europe, and the traces of historical rancor are still fresh in the hearts of people in the region. On the other hand, perhaps the nations of the South Caucasus are in need of more time to accommodate the traditional European approach to conflict resolution through cooperation and confidence building, a new phenomenon with which they have had to become familiar after reacquiring their independence. Whatever the reason, though, hopes should not be foregone that the EU could still make a difference in conflict resolution in the entire South Caucasus region employing this traditional model, even if this contribution may not be as target-oriented and effective as more direct involvement and more active conflict resolution efforts.

With respect to the EU's participation in the Geneva talks alongside the UN and the OSCE, the process is still new, with no concrete results so far. Of course, it is too early to judge the effectiveness or ineffectiveness of this format, given the fact that it has been operating for a shorter time span. There are many controversial issues discussed within this format - the most adamantly debated one being Georgia's demand to conclude a non-use agreement with Russia, which the latter rejects. Whatever could be the outcome of these talks, it remains a subject for future research. 


\section{Bibliography}

Belyi, Andrei. "EU External Energy Policies: A Paradox of Integration." In Europe's Global Role: External Policies of the European Union, 222. Farnham, UK: Ashgate, 2009.

Chryssochoou, Dimitrius N.. Theorizing European Integration. New York: Routledge, 2009.

Conflict Resolution in the South Caucasus: The EU's Role In International Crisis Group Europe Report., 2003.

Council Joint Action 2003., 2003.

Council Joint Action 2006., 2006.

Draft Report on an EU Strategy for the South Caucasus. European Parliament Committee on Foreign Affairs, 2010.

European Neighbourhood Policy: Strategy Paper In Communication from the Commission, final. Brussels, 2004.

Gault, John. "EU Energy Interests and the Periphery." In European Union Foreign and Security Policy: Towards a Neighbourhood Strategy, 171. London and New York: Routledge, 2004.

Geneva Talks on Caucasus End in Deadlock. AbkhazWorld, 2010.

Georgia's South Ossetia conflict: make haste slowly In International Crisis Group Europe Report., 2007.

Grono, Magdalena Frichova. Georgia's Conflicts: What Role for the EU as Mediator? In Initiative for Peacebuilding. IFP Mediation Cluster, 2010.

Indyk, Ari. Nicolas Sarkozy's Mediation of the Crisis in the Caucasus. PiCA, A Global Research Organization, 2009.

Lynch, Dov. The EU: Towards a Strategy In The South Caucasus: A Challenge for the EU, Chaillot Papers. Paris: European Union Institute for Security Studies, 2003.

Mikhelidze, Nona. Eastern Partnership and Conflicts in the South Caucasus: Old Wine in New Skins?., 2009.

Niemann, Arne. Explaining Decisions in the European Union. Cambridge: Cambridge University Press, 2006. 
Nugent, Neill. The Government and Politics of the European Union. Durham, NC: Duke University Press, 2006.

On a more effective EU policy for the South Caucasus: from promises to actions In European Parliament Resolution., 2008.

On the need for an EU strategy for the South Caucasus In European Parliament Resolution., 2010.

Popescu, Nicu. Europe's Unrecognized Neighbors: The EU in Abkhazia and South Ossetia In Working Document. Center for European Policy Studies, 2007.

Rosamond, Ben. "The Uniting of Europe and the Foundation of EU Studies: Revisiting the Neofunctionalism of Ernst B. Haas." In The Disparity of European Integration: Revisiting Neofunctionalism in Honor of Ernst B. Haas, 28. New York: Routledge, 2006.

Sarkozy, Nicolas. "Europe Gets Started on Quelling a Crisis." Washington Post (2008).

Sarkozy: Europe's Peacemaker or Was it all a Spin?. Economist.com, "Charlemagne's Notebook", 2009.

UN Mission in Abkhazia and Georgia to Close In Current Digest of the PostSoviet Press., 2009. 